\title{
NAZAL HAMARTOM
}

\author{
NASAL HAMARTOMA
}

\section{İbrahim ÇUKUROVA \\ Aytekin YAZ \\ Murat GÜMÜŞSOY \\ Gül Caner MERCAN \\ Ümit BAYOL \\ Orhan Gazi YİĞİTBAŞI}

\section{ÖZET}

Hamartom ya da hamartoma geliştiği organda normal olarak mevcut bulunan oluşturucu unsurlarla anormal bir karışımdan oluşan, tümör görünümlü bir doku malformasyonudur. Bu doku normal bir görünümde olsa da, fonksiyonları değişiktir. Çoğunlukla iyi huylu tümörlerdir. Neoplazmların aksine hamartomlar devamlı olarak çoğalma yeteneklerinin olmaması, kendilerini sınırlayan bir çoğalma ile sonuçlanırlar. Hamartomlar akciğer, karaciğer, böbrek, intestinal sistemden köken alma eğilimindedirler. Ancak üst solunum yollarında çok sık görülmezler. Nazal hamartomlar (NH) nadir olmakla birlikte yaygın olarak nazal septum ya da nazal kavite kaynaklıdırlar. Histolojik olarak yaygın alt tip serömüköz bezden değil solunumsal epitelden orijin alan glandular elemanların varlığıyla karakterize olan Respiratuar Epitelial Adenomatoid Hamartom (REAH)'dur. Bu özellik onları glandular elemanların serömüköz bezden orijin aldığı inflammatuar poliplerden ayırır. Hamartomaların etiyopatogenezi bilinmemektedir. Bu sunumumuzda REAH tespit edilen bir olgumuz ve nazal kaviteden orjin alan bu tümör tipinin literatürü gözden geçirilecektir.

Anahtar Sözcükler: Nazal hamartom, neoplazm, hamartom

\section{SUMMARY}

Hamartom or hamartoma is a tumor-looking tissue malformation that consist the mixture of normally forming elements of the developed organ and an abnormal elements. Although this tissue's appearance normal but functions is different. Mostly they are benign tumors. Hamartoma, unlike neoplasms, have not continuous growth ability, result of this limitting themselves to proliferation. Hamartoma tend to originate from lung, liver, kidney, intestinal system. However, upper respiratory tract is a uncommon location. Nasal hamartomas $(\mathrm{NH})$ are rarely seen but widely originate from nasal septum or nasal cavity. Histologically, the common sub-type is Respiratory Epithelial Adenomatoid hamartoma (REAH), which is characterized by the presence of glandular elements originating from the respiratory epithelium, not the serömüköz gland. Thisproperty separates themfromthe inflammatory polyps, that'sglandular elements originate from serömüköz glands. Hamartomas etiopathogenesis is unknown. This case present a REAH determined patient, and reviewing the literature of this type of tumor that originating from the nasal cavity.

Key Words: Nasal hamartoma, neoplasm, hamartoma

Tepecik Eğitim ve Araştır. Hast. K.B.B. Kliniği-İzmir (Op. Dr. İ. Çukurova, Op. Dr. A.Yaz, Op. Dr. M. Gümüşsüy, Op. Dr. G. C.Mercan, Prof. Dr. O. G. Yiğitbaşı) Tepecik Eğitim ve Araştır. Hast. Patoloji Lab.-̇̇zmir (Doç. Dr. Ü. Bayol)

Yazışma: Uzm. Dr. Murat GMÜŞSOY 


\section{GíRiş}

REAH ilk olarak 1995 yılında tanımlanmıştır. 1995 den önce literatürde sadece $13 \mathrm{NH}$ olgusu raporlanmıştır. Rapor edilen olguların büyük bölümünde cinsiyet erkek ağırlıklı olup yaş dağılımı 3 ay ile 20 yaş arasında değişmektedir. Hamartomlar olgun hücre grupları içeren yine de organize olmayan belirli bir bölgeye özelleşmiş hücre veya doku kitlesi oluşturabilen, uygunsuz farklılaşmış doku olarak tanımlanmıştır. Hücresel elemanlar olgun olup, organın başka yerlerinde bulunanlarla aynı olsa da, çevreleyen dokunun normal yapı yada fonksiyonunu üretemez. $\mathrm{Bu}$ lezyonlar benigndir. Hamartom ile benign bir neoplazmın birbirinden ayrılma çizgisi çok incedir ve yorumlanması çeşitlilik gösterir. Neoplazmların aksine hamartomların devamlı olarak çoğalma yetenekleri yoktur ve bu da kendini sinırlayan bir proliferasyonla sonuçlanmalarını sağlar. Hamartomlar akciğer, karaciğer, böbrek, intestinal sistemden de köken alma eğilimindedirler. Ancak üst solunum yollarında çok sık değildirler. NH nadir olmakla birlikte nazal septum ya da cavum nasi de orijin alabilirler. Histolojik olarak yaygın alt tip serömüköz bezden değil solunumsal epitelden orijin alan glandular elemanların varlığıyla karakterize olan REAH'dur. Bu özellik onları glandular elemanların serömüköz bezlerden orijin aldığ inflammatuar poliplerden ayırmaktadır $(1,2)$.

Siklıkla rastlanılan şikayetler; burun tıkanıklı̆̆ı, akıntısı ve kuruluğu, septum deviasyonu, epistaksis, yüz ağrısı, kronik sinüzit, koku alamamadır. $\mathrm{Bu}$ semptom ve bulguların ortaya çıkması birkaç aydan 8 yıla kadar sürebilir. Tanımlanan ortaya çıkış yerlerinin çoğu nazal kavite özellikle de posterior nazal septumdur. Lezyonun sağ veya sol kaviteye yerleşme eğilimi diye bir şey söz konusu değildir. Hatta sıklıkla her iki kaviteye yerleşir. Radyolojik olarak REAH'ların en çok görülen bulgusu etkilenen sinüsün opasitesi ve septumla olan kısmi bağlantısıdır. Erozyon yapmayıp zayıf yayılması yavaşça geliştiğinin bir göstergesidir. REAH'ların paranazal sinüs bilgisayarlı tomografi (PNSBT) bulgusu olan olfaktör yarı̆̆ın genişlemesine neden olduklar bilinmektedir. 15 REAH'lu, 36 nazal polipli ve 49 adet herhangi bir sinüs hastalığı olmayan olgunun aksiyel ve koronal plandaki PNSBT lerini gözden geçirilmesi sonucunda REAH'ların olfaktör yarığı enine genişlettikleri, bu ayrıntı bilateral lezyonu olan hastaların nazal poliple ayırıcı tanısında önemli bir referans noktası kabul edilmektedir. REAH olgularının birçoğu biyopsiye gider. Bu tanıyı koymak önemlidir çünkü REAH'lı olguların tedavisi basit eksizyon iken diğer tanılı olguların tedavisi daha kompleks cerrahilerdir. REAH'un diğer bir olumlu karekteristik özelliği, komplet eksizyon küratif olup ve mükemmel prognozu vardır. Bazı olgularda eksizyon sonrası 5 yıl hiç rekürens görülmemiştir (1-3).

\section{OLGU 1}

70 yaşında bayan olguda 6 aydır olan burun tıkanıklığ 1 ve burun kanaması yakınması ile geldi. Fizik muayenesinde; $4 \mathrm{~mm}, 0^{0}$ rijid teleskop ile yapılan nazal endoskopi sonucunda nazal septumdan kaynaklanan, sol nazal pasajı tamamen kapatan, anterior septumda perforasyona yol açıp sağ nazal pasaja uzanım gösteren kitle saptandı (Resim 1,2).

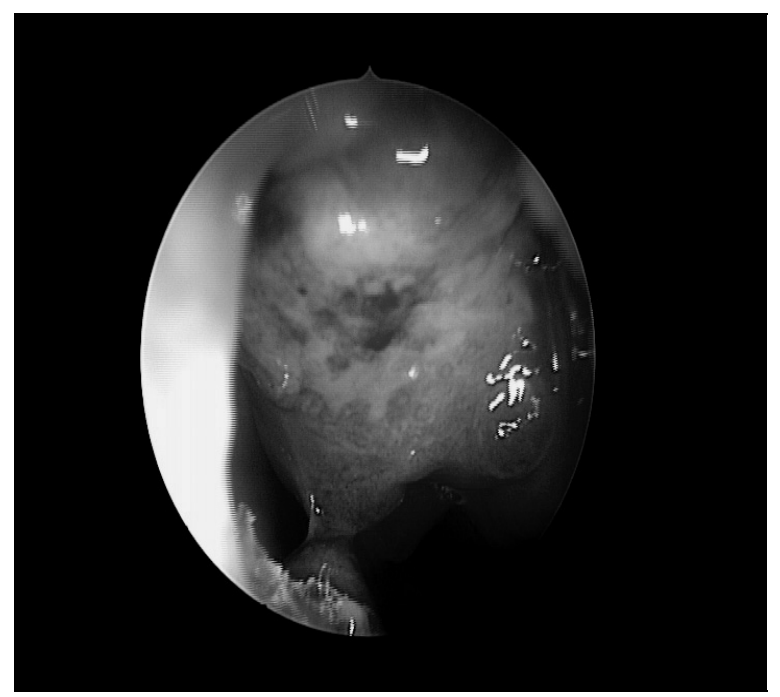

Resim 1. Sol nazal pasajdaki kitlenin endoskopikgörüntüsü.

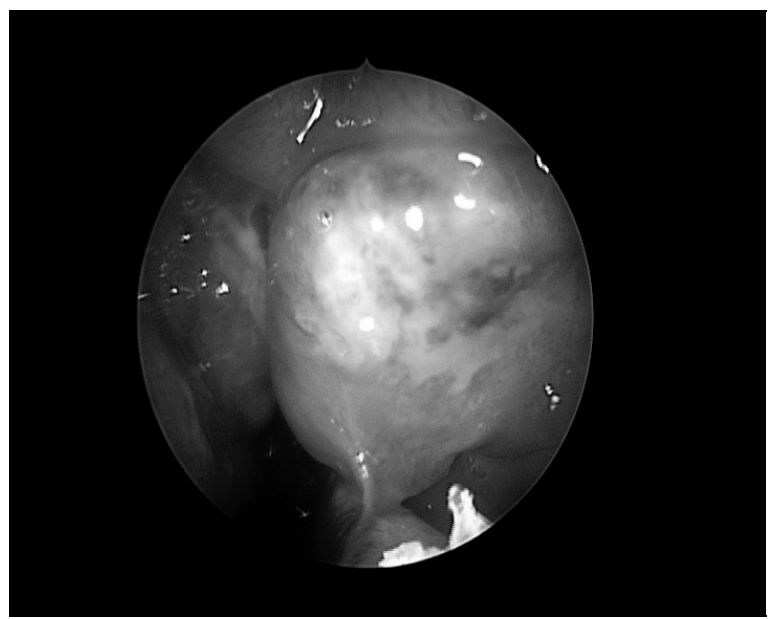

Resim 2. Septumu destrükte ederek sol nazal pasaja uzanan kitlenin görüntüsü. 
PNSBT görüntülerinde bilateral frontal sinüsler hipoplazik görünümde olup sol maksiller ve sol etmoidal sinüste çok az bir havalanma mevcudiyeti dışında, bilateral maksiller, etmoidal, frontal ve sfenoid sinüste tamamen havalanma kaybına yol açan ve iç yapısını tamamen dolduran yumuşak doku dansitesi izlenmiştir. Osteomeatal kompleksler obliteredir (Resim 3).

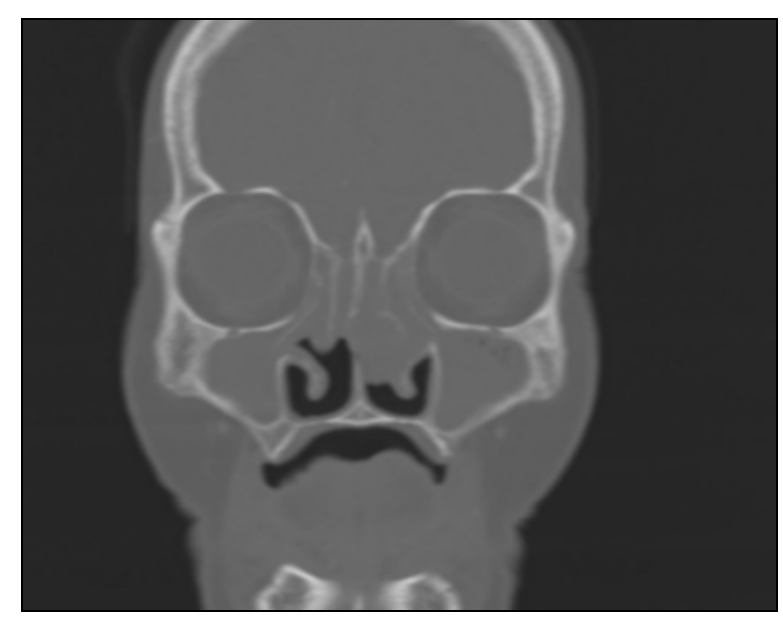

Resim 3. Olgunun preoperatif PNSBT görüntüsü

Kitle genel anestezi altında endoskopik olarak total olarak eksize edildi. Çıkarılan spesmen parlak, elastik görünümde olup $6 * 5 * 1,5 \mathrm{~cm}$ büyüklüğündeydi (Resim 4).

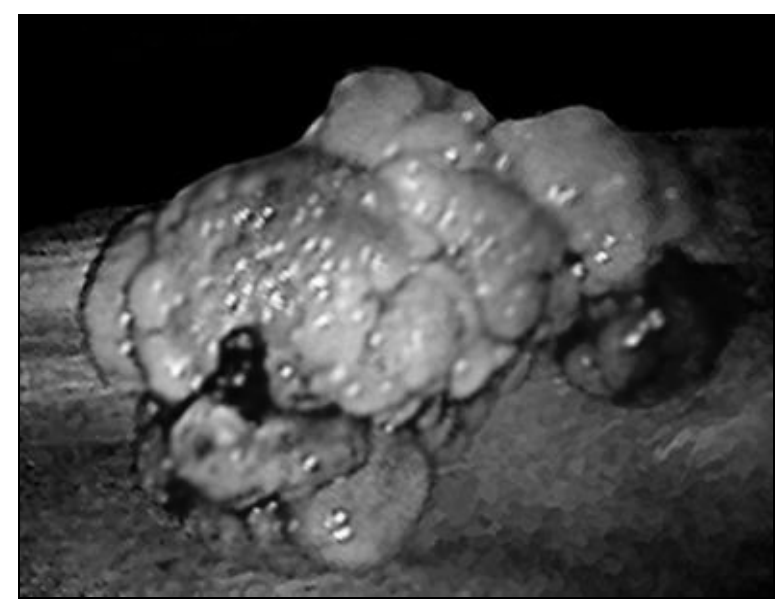

Resim 4. Endoskopik olarak total eksize edilen materyalin makroskopik görünümü.

Patolojik incelemesinde solunumsal epitelden orijin alan glandular elemanlar, olgun lenfosit ve plazma hücrelerinden oluşan karışık inflamatuar hücre infiltrasyonu saptandı (Resim 5).

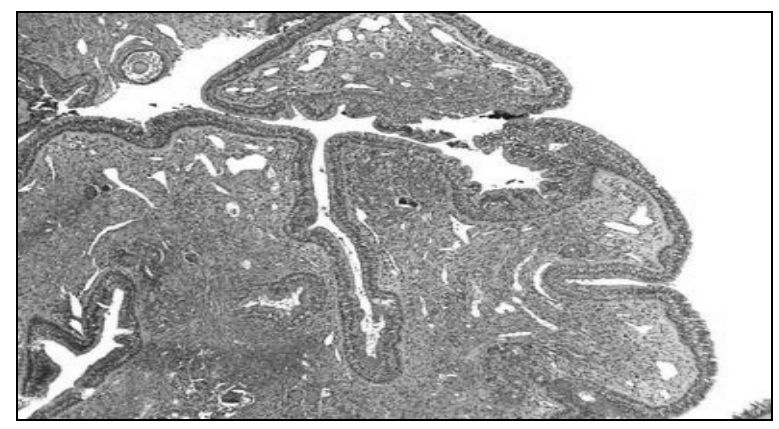

Resim 5. Respiratuar epiteliyal adenomatoid hamartom mikroskopik görüntüsü(HE*100).

Metaplazi ve atipik hücreler saptanmadı. REAH teşhisi kondu. Cerrahi sonrası 8 aylık nazal endoskopik takiplerinde halen asemptomatik ve rekürens belirtisi yoktur.

\section{OLGU 2}

40 yaşında erkek olguda, 3 yıldır burun tıkanıklığı, burun akıntısı, koku alamama yakınmaları ile polikliniğimize başvurdu. Fizik muayenesinde sağ nazal pasajı tamamen kapatan, koanal protrüzyona neden olan kitle saptand1 (Resim 6).

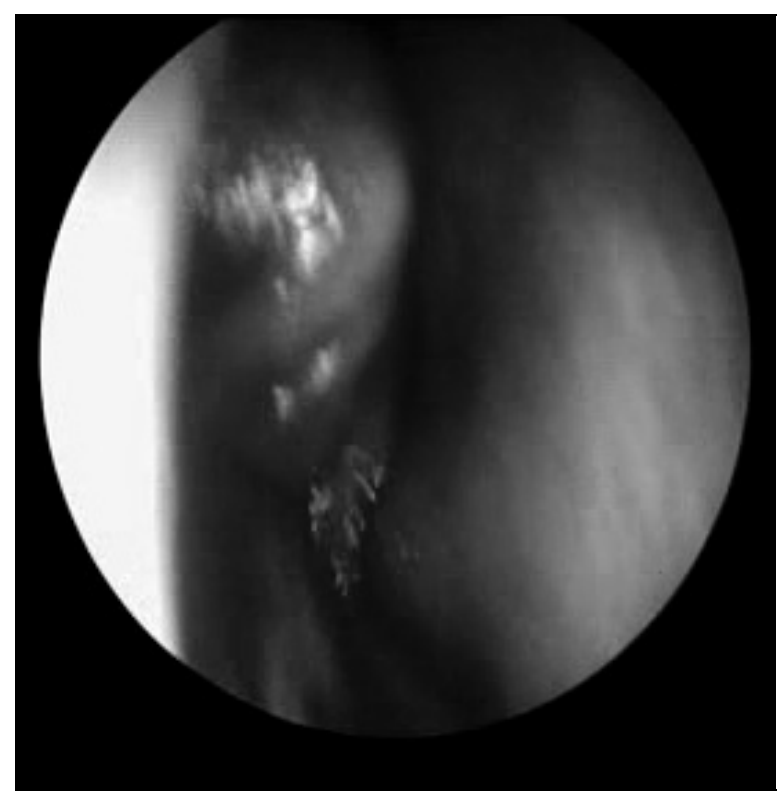

Resim 6. Sağ nazal pasajdaki kitlenin endoskopik preoperatif görüntü.

PNSBT görüntülemesinde; sağda nazal kaviteyi dolduran, etmoid, maksiler ve frontal sinüsleri kaplayan kitle gözlendi. Kemik destrüksiyonu saptanmadı (Resim 7). Kitle genel anestezi altında transnazal endoskopik cerrahi ile total olarak çıkarıldı (Resim 8). 


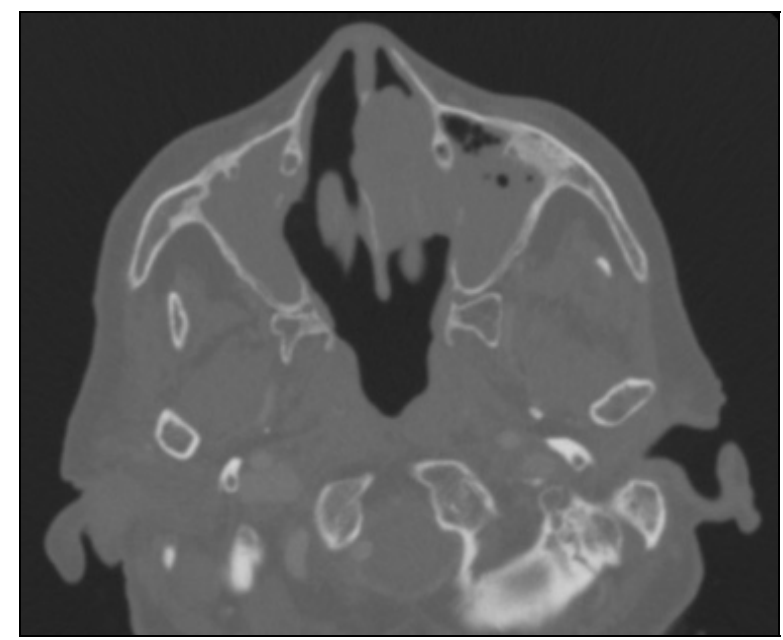

Resim 7. Preoperatif sağ nazal pasajdaki kitlenin PNSBT görüntüsü.

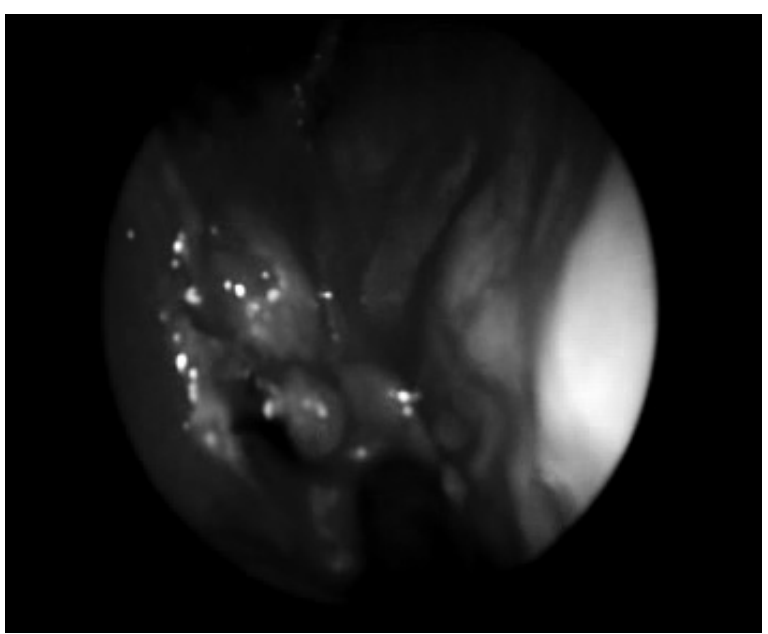

Resim 8. Postoperatif sağ nazal pasajın endoskopik görüntüsü

Çıkartılan doku elastik, sert ve parlak yüzeyli, boyutları $4 * 3,7 * 2 \mathrm{~cm}$ boyutlarındaydi. Patolojik inceleme sonucunda REAH tanisı kondu. Olgumuz cerrahi sonras1 18 aylık takiplerinde asemptomatik ve rekürens belirtisi saptanmadi.

\section{TARTIŞMA}

NH'ların çoğu özellikle posterior superior alanda olmak üzere nazal septumda bulunur. NH'un semptomları burun tıkanıklığı, burun akıntısıyla giden kronik sinüzite benzerdir. Bazı hastalarda tekrarlayan burun kanamalariyla seyreder. PNSBT veya MR görüntülemeleri karakteristik değildir ${ }^{(1)}$.

Hamartomlar benign, kendi kendini sinırlayan lokal olarak agresif lezyonlardır. Vasküler hamartomlar bu agresif seyirlerine karşıı kötü huylu değişim göstermezler. Klinik inflamasyonla birlikte olan nazal polipten orijin aldığına dair görüşler olmasına rağmen hamartomaların kesin etiyopatogenezi bilinmemektedir. Bu da çeşitli embriyolojik orijinlerden kaynaklanan hamartomaların birbirleri ile histopatolojik benzerlikleri açıklar. Herhangi bir etiyolojik ajanla özellikle tütün veya alkol tüketimiyle de herhangi bir ilişkisi gösterilmemiştir $(1,2)$.

Flavin ve arkadaşları nazal hamartomların toplam insidansını 20.000-40.000 doğumda bir olarak rapor etmişlerdir (3). Olguların çoğunluğu infant iken kendini göstermekle beraber, Kessler ve arkadaşları 2 adolesan ve 2 yetişkin hamartom olgusuna rastlamışlardır (4). Malinvaud ve arkadaşları retrospektif taramalarında 18 yıllık bir süre periyodunda 135 hamartom tanısı alan çocuk olgu tariflenmiştir (5). Vasküler ve lenfatik lezyonlar en sık olarak hamartom olarak sınıflandırılan olguların \%13 ünde bulunmuştur. Owens ve arkadaşları bir çocuk cerrahi ünitesinde 30 yıllık süre içerisinde oral kitle tanısı konan 95 olgunun yapılan retrospektif incelemelerinde, olguların 83 'ünde benign lezyon ve 22 'sinde hamartom bulmuşlardır.

İzole hamartomlar orta kulakta ve mastoid kavitede de rapor edilse de en sik nazofarenksin lateral duvar ve yumuşak damakta bulunur. Bu tümörlerin etyolojisi bilinmemektedir ve nazofarengeal membranın regrese olamamasından pluripotent dokunun yanlış yönlendirilmesine kadar pek çok mekanizma ileri sürülmüştür. Prosedürün en önemli aşaması cerrahi olarak çıarılan parçanın histopatolojik incelemesidir. REAH değişik varyasyonda özellikler gösterebilir. Asıl morfolojik görünüm gland ve duktusların psödostratifiye silli epitelle çevrili olarak metaplastik değişiklik olmadan proliferasyonu ve bir araya gelmesidir. Patologların REAH'la karıştırdığı en sık iki patoloji inverted papillom ve adenokar-sinomdur. İnverted papillom sinonazal mukozanın Schneideriaen epitelinden köken alır, endofitik büyüme ile birlikte epidermoid veya squamoz epitelyal proliferasyonun yoğunlaşmasından oluşur. Tedavisi yüksek lokal rekürens riski taşıyan endoskopik veya eksternal transnazal yaklaşımla radikal rezeksiyon gerektirir. Adenokarsinom yüzey epitelinden veya küçük tükrük bezlerinden kaynaklanır. Ayrıca pleomorfizm ve artmış mitotik aktivite ile birlikte arka arkaya proliferasyon paterni gösteren kompleks glandular büyümeden oluşur. İmmunhistokimyasal çalışmalar REAH ile neoplazmların ayrılmasında yardımcı olur. Ayrıca radyolojik görüntülemelerde; adenokarsinomların agresif davranışı, kemik dekstrüksüyonu ve 
yumuşak dokuya invazyonu şüphe uyandırmalıdır. Komplet rezeksiyon yeterli olur ve prognoz oronazofarengeal benign neoplazmlar için mükemmeldir. Şimdiye kadar malign transformasyon rapor edilmemiştir (3).

\section{SONUÇ}

Klinik olarak üst solunum yolu semptomları ile rastlanılan, her yaş grubunda rapor edilmiş olsalar da, daha çok erkeklerde rapor edilen genişleyici ve yer kaplayan bir kitledir. Histolojik özellikleri solunum yüzey epitelinden orijin alan glandular proliferasyonu ve REAH ile sonuçlanan polipoid büyümeyi içerir. Glandların üzerini çizen kolumnar hücreler sillidir. Uygun olmayan teşhis bu lezyonun histopatolojik olarak incelenmesinde önemli bir konudur. Patologların yanlış tanıdan kaçınmaları ve hastaların normalden fazla cerrahi girişime maruz kalmamaları için dikkatli olmaları gerekmektedir. Yanlış tanı bu benign tümörü uygunsuzca radikal agresif cerrahiye götürebilmektedir. $\mathrm{Bu}$ nedenle nazal kitlenin komplet, enblok eksizyonu, özellikle burun içerisinde NH'nin

\section{ILETişim}

Uzm. Dr. Murat GÜMÜŞSOY

S.B. İzmir Tepecik Eğitim ve Araştırma Hastanesi

K.B.B. Kliniği-İzmir

E-mail: mgumussoy@hotmail.com köken aldığı lokalizasyonu tam olarak belirlenip tamamen çıkarılması, seçilecek en uygun tedavi seçeneğidir. Literatür incelemesi sonucunda da, izlenen bu yöntem sonrasında NH'ların rekürensi gözlenmemiştir.

\section{KAYNAKLAR}

1. Alrawi M, McDermott M, Orr D, Russell J. Nasal chondromesynchymal hamartoma presenting in an adolescent. Int J Pediatr Otorhinolaryngol 2003; 67: 669-672.

2. Delbrouck C, Fernandez Aguilar S, Choufani G, Hassid S.Respiratory epithelial adenomatoid hamartoma associated with nasal polyposis. Am J Otolaryngol 2004; 25: 282-284.

3. Flavin R, Russell J, Phelan E, McDermott MB. Chondroosseous respiratory epithelial adenomatoid hamartoma of the nasal cavity: a case report. Int J Pediatr Otorhinolaryngol. 2005 Jan; 69(1): 87-91.

4. Kessler HP, Unterman B. Respiratory epithelial adenomatoid hamartoma of the maxillary sinus presenting as a periapical radiolucency: a case report and review of the literature. Oral Surg Oral Med Oral Pathol Oral Radiol Endod 2004; 97: 607612.

5. Malinvaud D, Halimi P, Cote JF, Vilde F, Bonfils P. Adenomatoid hamartoma of the ethmoid sinus: one case report. Rev Laryngol Otol Rhinol (Bord) 2004; 125: 45-48. 